\title{
PENERAPAN METODE DESAIN SPRINT PADA SISTEM PENDISTRIBUSIAN DAN PENGADAAN BARANG MENGGUNAKAN MOBILE
}

\author{
Adhie Thyo Priandika'), Wahyu Widiantoro' ${ }^{2)}$ \\ 1,2 Informatika, Universitas Teknokrat Indonesia \\ 1,2 Jl. Z.A. Pagar Alam No 9-11, Kedaton, Bandar Lampung, Lampung 35141 \\ Email: '1adhie_thyo@teknokrat.ac.id, ${ }^{2}$ wahyu_widiantoro@teknokrat.ac.id
}

\begin{abstract}
CV Ra'Abas Bandarlampung is a trading business engaged in the distribution and procurement of goods that distributes its merchandise to customers. Problems that exist in the distribution process, namely the manufacture of sales notes and invoices for delivery still done manually, namely by writing on notes and invoices for delivery of goods to be given to customers so that it slows down employee performance. The sprint method is a method for building product concepts and prototypes within 5 minutes. a day where it has 5 very communicative and interactive stages to bring out all ideas, inspiration, creativity, existing problems.. The next stage is to make a sketch of the application to be built, the sketch made is a sketch for the login display, dashboard, customer data, goods data, supplier data, procurement data, receipt data, and goods distribution data. The next stage is to make a decision from the previous stage by determining the results of the sketch that has been made from the procurement and distribution system of goods that can overcome the problems that occur in CV Ra'Abas.
\end{abstract}

Keyword: Application, Distribution, System, Website, Sprint

\begin{abstract}
Abstrak
CV Ra'Abas Bandarlampung sebuah usaha dagang yang bergerak pada bidang pendistribusian dan pengadaan barang yang mendistribusikan barang dagangannya kepada pelanggan. Permasalahan yang ada pada proses pendistribusian yaitu pembuatan nota penjualan dan faktur pengiriman barang masih dilakukan secara manual yaitu dengan menulis pada nota dan faktur pengiriman barang. Metode sprint adalah suatu metode untuk membangun konsep produk dan prototype dalam waktu 5 hari dimana memiliki 5 tahapan yang sangat komunikatif dan interaktif untuk mengeluarkan semua ide, inspirasi, kreatifitas, masalah-masalah yang ada. Tahapan selanjutnya adalah membuat sketsa dari aplikasi yagn akan dibangun, sketsa yang dibuat adalah sketsa untuk tampilan login, dashboard, data pelanggan, data barang, data supplier, data pengadaan, data penerimaan, dan data pendistribusian barang. Tahapan selanjutnya adalah mengambil keputusan dari tahapan sebelumnya dengan menentukan hasil dari sketsa yang telah dibuat dari system pengadaan dan pendistribusian barang dapat mengatasi permasalahan yang terjadi pada CV Ra'Abas.
\end{abstract}

Kata Kunci: Aplikasi, Distribusi, Sistem, Website, Sprint

\section{Pendahuluan}

Teknologi informasi berperan dalam aktivitas manusia pada saat ini memang begitu besar sehingga teknologi informasi telah menjadi fasilitator utama bagi kegiatan-kegiatan bisnis, memberikan andil yang begitu besar terhadap perubahan-perubahan [1]. Teknologi informasi tidak hanya penting sebagai alat komunikasi via elektronik saja, melainkan merupakan perangkat penting yang seharusnya dimiliki dalam bisnis sebagai sarana untuk berkoordinasi dan pengarsipan dokumen-dokumen penting [2]. Teknologi Informasi diterapkan guna untuk pengelolaan informasi yang pada saat ini menjadi salah satu bagian penting karena meningkatnya kompleksitas dari tugas manajemen [3].

CV Ra'Abas Bandarlampung sebuah usaha dagang yang bergerak pada bidang pendistribusian dan pengadaan barang yang mendistribusikan barang dagangannya kepada pelanggan. Proses pendistribusian barang yang dilakukan masih secara konvensional yaitu melakukan pencatatan pada nota pendistribusian barang yang akan dikirim kepada pelanggan. Permasalahan yang ada pada proses pendistribusian yaitu pembuatan nota penjualan dan faktur pengiriman barang masih dilakukan secara manual yaitu dengan menulis pada nota dan faktur pengiriman barang untuk diberikan kepada pelanggan sehingga memperlambat kinerja karyawan dalam pengolahan transaksi pendistribusian. Sehingga perlu membuat sebuah sistem informasi pendistribusian dan pengadaan barang pada CV Ra'Abas Bandarlampung untuk mempermudah perusahaan dalam pengolahan data transaksi pendistribusian dan pengadaan barang.

Metode sprint adalah suatu metode untuk membangun konsep produk dan prototype dalam waktu 5 hari dimana memiliki 5 tahapan yang sangat komunikatif dan interaktif untuk mengeluarkan semua ide, inspirasi, 
kreatifitas, masalah-masalah yang ada, solusi yang kemudian diwujudkan dalam prototype [4], [5]. Tahapan pertama adalah membuat pemahaman terhadap pembahasan tentang aplikasi pendistribusian dan pengadaan barang serta menentukan permasalahan dari Pendistribusian dan Pengadaan Barang. Tahapan kedua adalah membuat persona yang menggambarkan pengguna produk, karakteristik pengguna, kebutuhannya. tahapan ketiga adalah mengeluarkan solusi-solusi dengan beberapa aktifitas yang menarik seperti mindmap, crazyeights, dan silentcritique. Tahapan keempat yaitu fase menyaring ide-ide ke dalam satu atau dua solusi yang dapat diuji. tahapan kelima adalah membuat konsep prototype aplikasi pendistribusian dan pengadaan barang.

\section{Metode}

Dalam penelitian yang menerapkan metode sprint kali ini penulis membentuk sebuah kerangka penelitian sebagai bentuk langkah yang akan dilakukan dalam penelitian adapun sebagai berikut

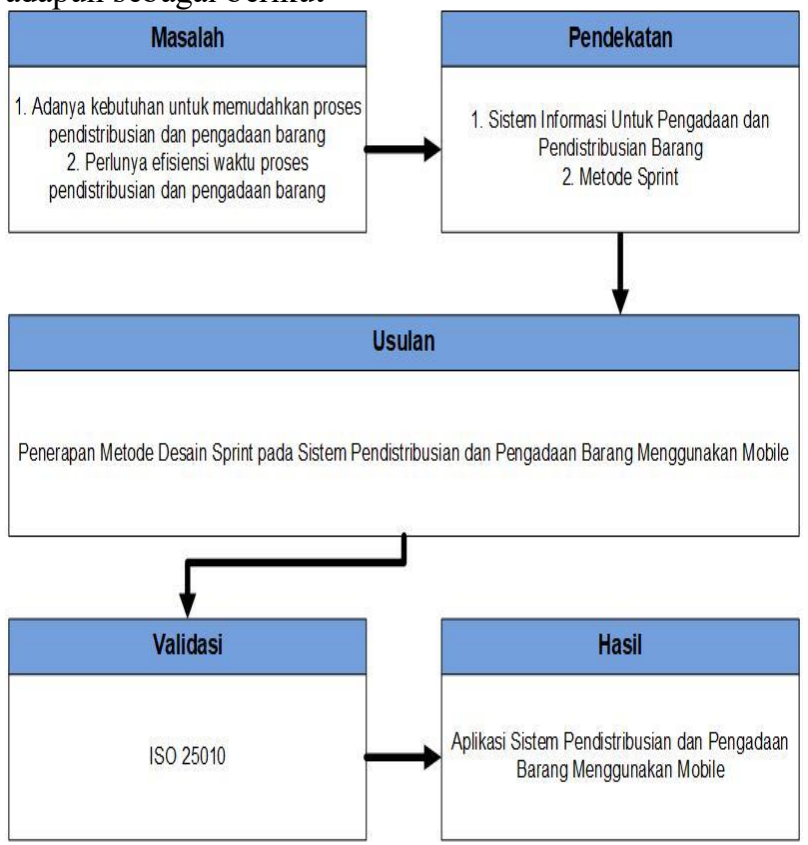

Gambar 1. Kerangka Penelitian

\section{Metode Pengumpulan Data}

1. Wawancara (Interview)

Pengumpulan data dengan metode interview yaitu metode pengumpulan data dengan cara tanya jawab secara langsung dengan orang-orang yang terkait pada pihak perusahaan

2. Pengamatan (Observation)

Pengumpulan data dengan mengamati atau observation yaitu metode pengumpulan data dengan cara pengamatan dan pencatatan secara langsung. Mempelajari segala sesuatu yang berhubungan dengan sistem yang ada saat ini.

3. Dokumentasi (Documentations)

Merupakan metode pengumpulan data dengan cara membaca, mencatat, mengutip, dan mengumpulkan data-data secara teoritis dari buku-buku dan Internet sebagai landasan penyusunan penelitian.

\section{Hasil dan Pembahasan}

\section{a. Usecase Diagram}

Use case diagram mendeskripsikan sebuah interaksi antara satu atau lebih aktor dengan sistem yang akan dibuat [6]. Dalam usecase kali ini dijelaskan bahwa admin dapat melakuka akses dan juga pengelolaan terhadap sistem dengan pimpinan dapat melihat dan juga mencetak laporan.

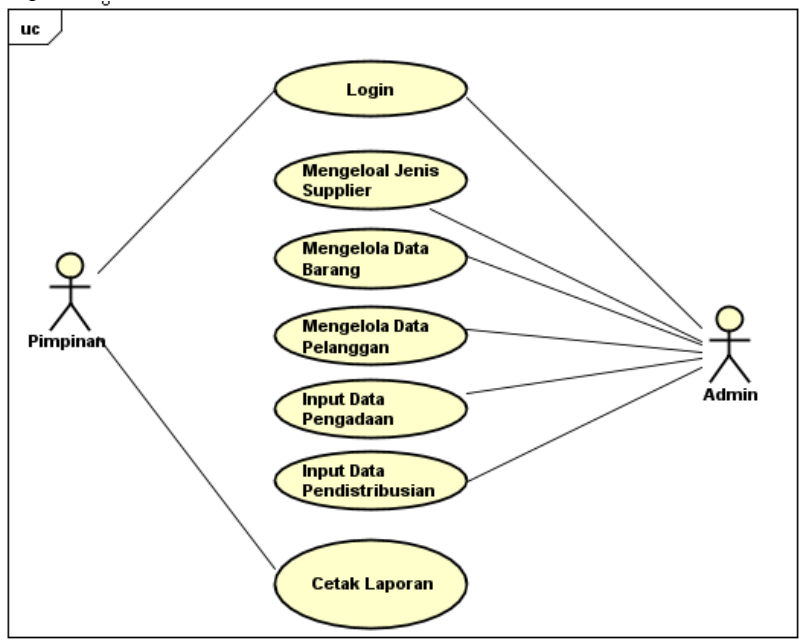

Gambar 2. Usecase Diagram

\section{b. Class Diagram}

Class diagram merupakan penentuan komponen entitas dari sistem yang nantinya akan diterapkan sebagai acuan dalam membangun database, dalam pembuatan sistem ini terdapat beberapa entitas yang dibuat yaitu seperti entitas barang, pengadaan, supplier, pelanggan, distribusi, dan penerimaan.

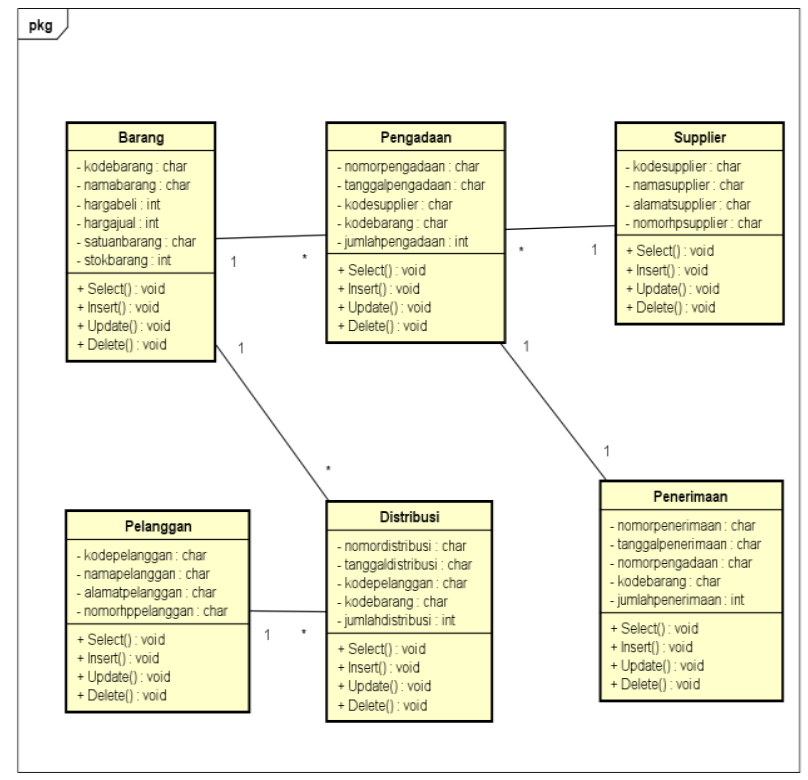

Gambar 3. Class Diagram

\section{c. Metode Desain Sprint}

Metode Sprint memberikan kekuatan yang dahsyat pada startup yang memangkas perdebedatan yang tidak 
diperlukan dan meminmalisir pekerjaan yang membutuhkan waktu berbulan-bulan ke menjadi pekerjaan yang dilakukan dalam 1 minggu. Metode ini juga memungkinkan untuk mempercepat agar hasil akhir produk dapat terlihat dan menilai respon dari customer.

Membangun sistem pengadaan dan pendistribusian pada CV Ra'Abas ini dengan menggunakan metode Desain Sprint yaitu melakukan pemetaan (mapping) dalam tahapan ini melakukan identifikasi permasalahan yang terjadi dan merumuskan solusi dari permasalahan sistem pengadaan dan pendistribusian barang adalah dengan membangun sebuah system yang berbasis mobile untuk mengatasi permasalahan yang terjadi pada CV Ra'Abas. Tahapan selanjutnya adalah membuat sketsa dari aplikasi yagn akan dibangun, sketsa yang dibuat adalah sketsa untuk tampilan login, dashboard, data pelanggan, data barang, data supplier, data pengadaan, data penerimaan, dan data pendistribusian barang. Tahapan selanjutnya adalah mengambil keputusan dari tahapan sebelumnya dengan menentukan hasil dari sketsa yang telah dibuat dari system pengadaan dan pendistribusian barang dapat mengatasi permasalahan yang terjadi pada CV Ra'Abas. Tahapan selanjutnya adalah membuat rancang bangun aplikasi pengadaan dan pendistribusian barang menggunakan bahasa pemrograman PHP dengan database MySql. Tahapan terakhir adalah melakukan pengujian dari aplikasi yang telah dibuat kepada pengguna [7].

\section{d. Implementasi}

Implementasi sistem adalah langkah-langkah atau prosedur yang dilakukan untuk menyelesaikan desain sistem yang disetujui, menginstal, menguji, dan menjalankan sistem baru atau yang ditingkatkan [8]. Tujuan dari penerapan sistem ini adalah untuk melengkapi desain sistem yang telah disetujui sebelumnya, pengguna dapat mengoperasikan sistem baru [9]. Uji apakah sistem baru sesuai dengan kebutuhan pengguna. Untuk memastikan bahwa peralihan ke sistem baru berfungsi, perencanaan, pengendalian, dan implementasi yang tepat dari fasilitas baru harus dipastikan. Implementasi sistem pendistribusian dan pengadaan barang dengan menggunakan metode desain sprint.

Implementasi halaman login merupakan tampilan yang digunakan sebagai sebagai hak akses ke halaman login, berikut adalah tampilan login pada gambar 4. dibawah ini

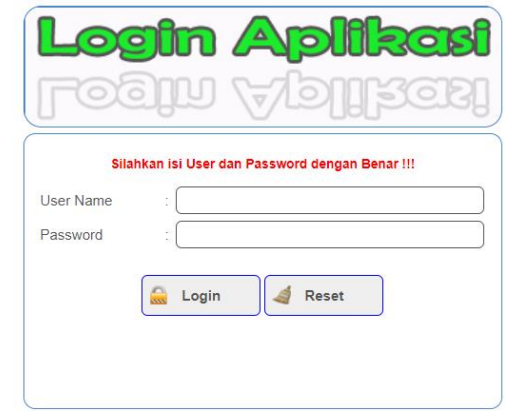

Gambar 4. Halaman Login

Implementasi halaman dashboard merupakan tampilan yang digunakan untuk menampilkan data dan mengakses data, berikut adalah halaman dashboard pada gambar 5. dibawah ini I BARAMGPEИGADAAИ DAИ PEИDISGRIBUSLAИ BARAИGPEИGADAA MPUMGCV. RA ABAS BAИDAR GAMPUИGCV. RA"

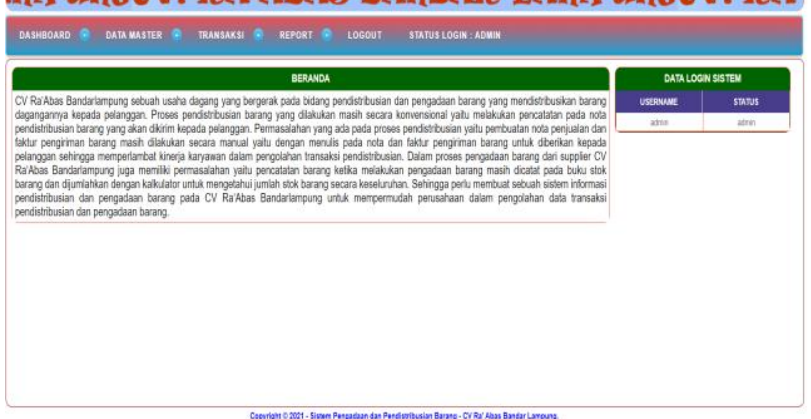

Gambar 5. Halaman Dashboard

Implementasi halaman data barang merupakan tampilan yang digunakan untuk menampilkan data barang, berikut adalah halaman data barang pada gambar 6 . dibawah ini

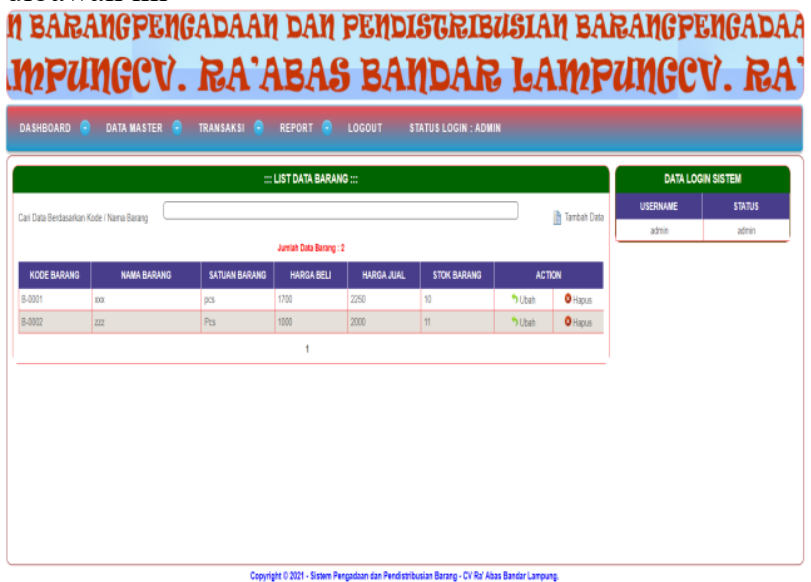

Gambar 6. Halaman Data Barang

Implementasi halaman data pengadaan merupakan tampilan yang digunakan untuk menampilkan data pengadaan, berikut adalah halaman data pengadaan pada gambar 7. dibawah ini

ARAИGPEИGADAAИ DAИ PEИDISTRIBULLAИ BARAИGPEИGAI PUHGCV. PA ABAS BALDAR GAMPTHGCV. R

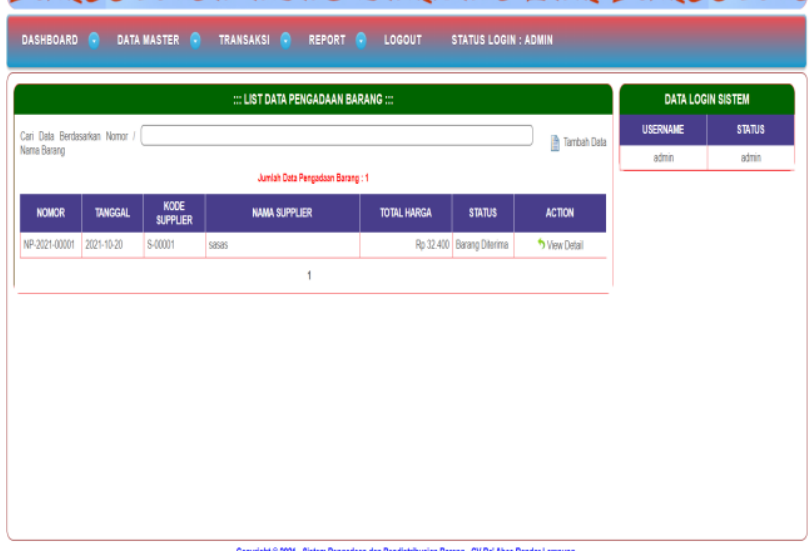

Gambar 7. Halaman Data Pengadaan Barang

Implementasi halaman tambah data pengadaan 
merupakan tampilan yang digunakan untuk menambah data pengadaan, berikut adalah halaman tambah data pengadaan pada gambar 8 . dibawah ini

ARAИGPEИGADAAИ DAИ PEИDIGTRIBULLAИ BARAИGPEИGAI PUHGCV. PA ABAS BAИDAR GAMPUHGCV. P

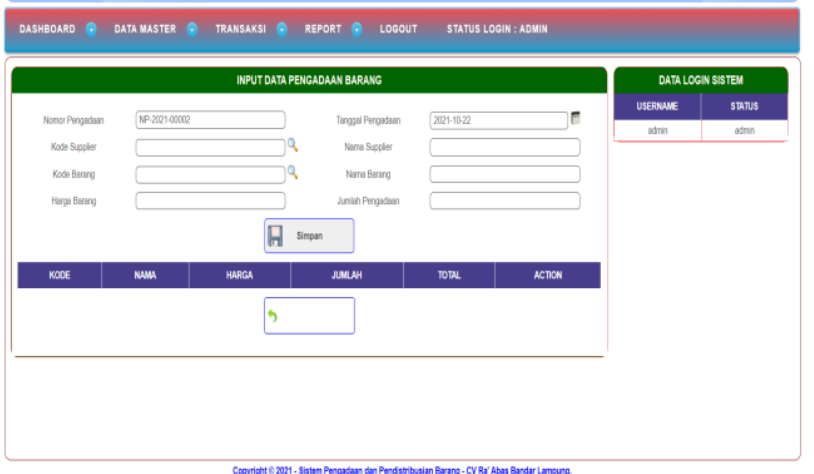

Gambar 8. Halaman Data Tambah Pengadaan Barang

Implementasi halaman data pendistribusian merupakan tampilan yang digunakan untuk menampilkan data pendistribusian, berikut adalah halaman data pendistribusian pada gambar 9. dibawah ini

ARAИGPEИGADAAИ DAИ PEИDISTRIBUILИ BARAИGPEИGAI PUMGCV. RA'ABAS BAYDAR GAMPUMGCV. R

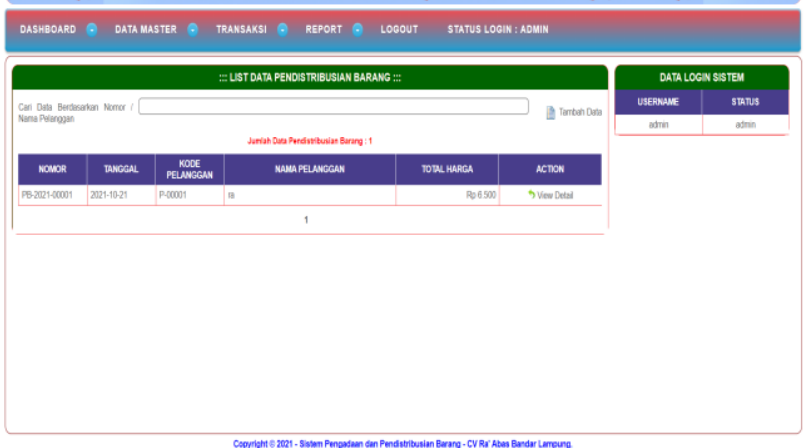

Gambar 9. Halaman Data Pendistribusian

Implementasi halaman tambah data pendistribusian merupakan tampilan yang digunakan untuk menambah data pendistribusian, berikut adalah halaman tambah data pendistribusian pada gambar 10 . dibawah ini

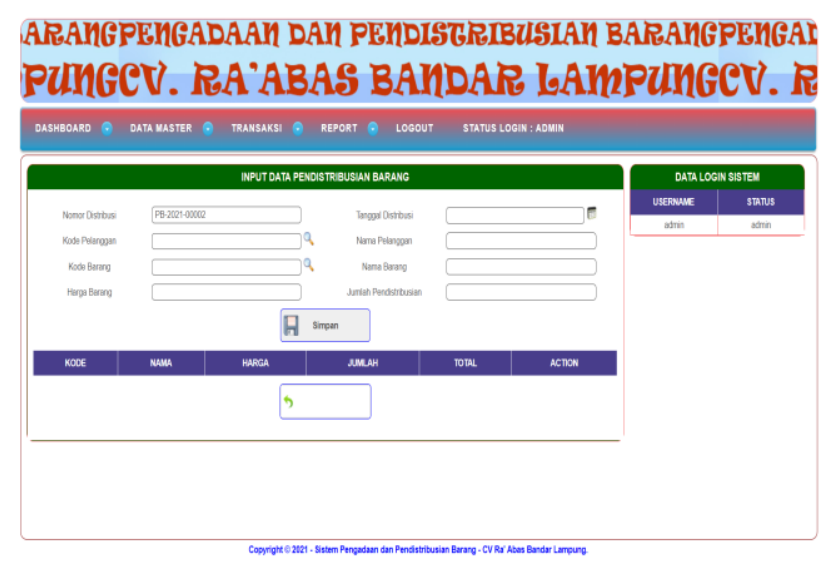

Gambar 10. Halaman Tambah Data Pendistribusian

\section{e. Pengujian}

Black box testing atau yang sering dikenal dengan sebutan pengujian fungsional merupakan metode pengujian perangkat lunak yang digunakan untuk menguji perangkat lunak tanpa mengetahui struktur internal kode atau Program [10]. Pengujian dilakukan terhadap aplikasi untuk memastikan bahwa aplikasi dapat berjalan dengan benar sesuai dengan kebutuhan dan tujuan yang diharapkan [11]. Proses pengujian terhadap aplikasi akan menggunakan black box testing.

Pengujian black box untuk mengetahui kesesuaian fungsi pada penerapan metode desain sprint pada sistem pendistribusian dan pengadaan barang menggunakan mobile yang dibangun. Berikut ini adalah hasil dari pengujian black box testing yang terdapat pada sistem pengadaan dan pendistribusian barang.

Tabel 1. Pengujian Blackbox Testing

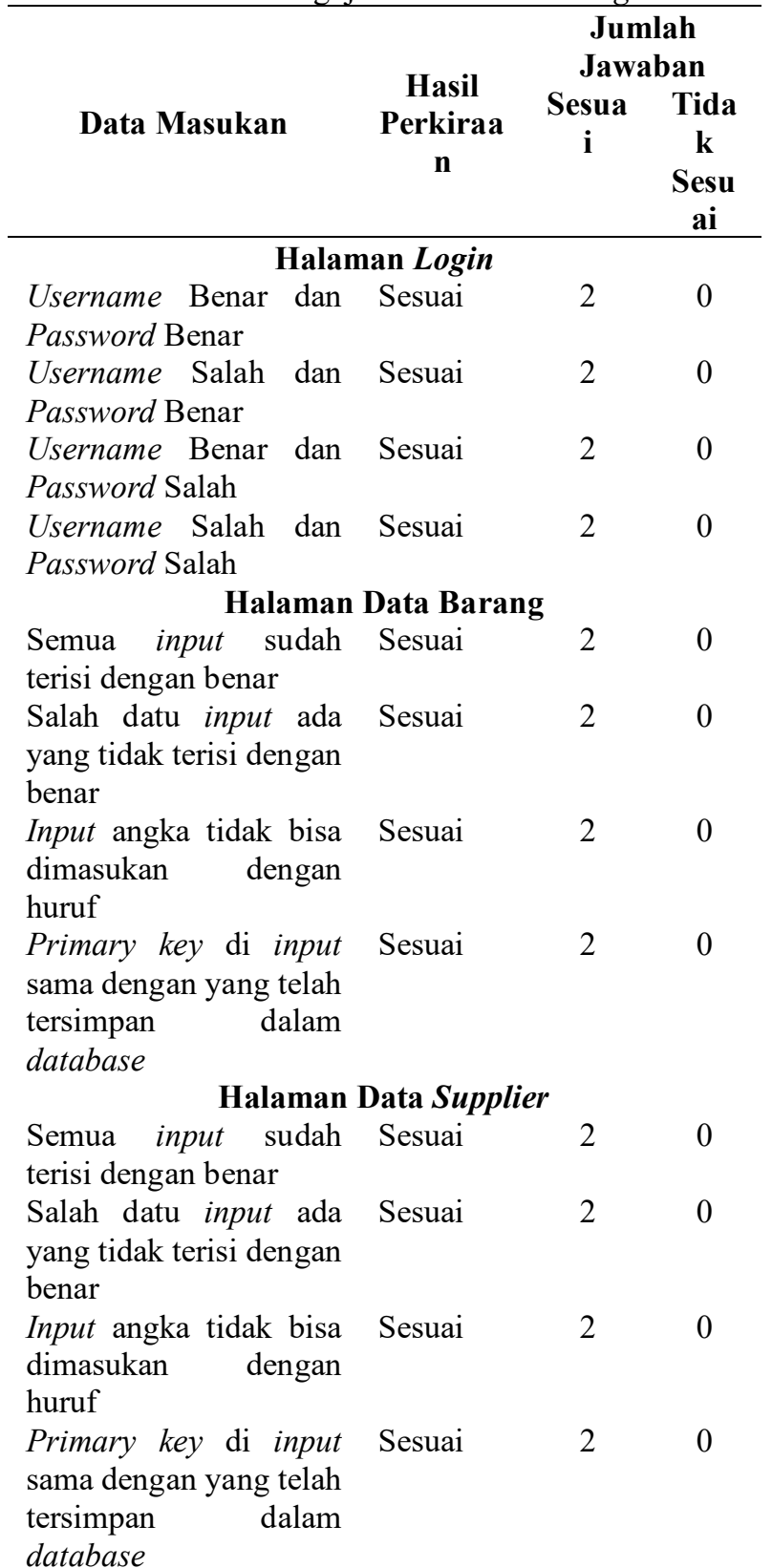


Halaman Data Pelanggan

$\begin{array}{llll}\begin{array}{l}\text { Semua input sudah } \\ \text { terisi dengan benar }\end{array} & \text { Sesuai } & 2 & 0 \\ \begin{array}{l}\text { Salah datu input ada } \\ \text { yang tidak terisi dengan }\end{array} & & 2 & 0 \\ \text { benar } & & & \\ \begin{array}{l}\text { Input angka tidak bisa } \\ \text { dimasukan desuai }\end{array} & 2 & 0 \\ \text { huruf } & & & \\ \begin{array}{l}\text { Primary key di input } \\ \text { sama dengan yang telah } \\ \text { tersimpan dalam } \\ \text { database }\end{array} & & 2 & 0 \\ \end{array}$

database

\section{Halaman Data Pengadaan}

Semua input sud terisi dengan benar

Salah datu input ad

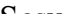

20

yang tidak terisi dengan

Sesuai $2 \quad 0$

benar

Input angka tidak bisa dimasukan dengan

Sesuai

2

huruf

Halaman Data Penerimaan 2 terisi dengan benar

Salah datu input ada Sesuai

yang tidak terisi dengan

benar

Input angka tidak bisa dimasukan dengan

Sesuai

huruf

\section{Halaman Data Pendistribusian}

Semua input sudah Sesuai 2 terisi dengan benar

Salah datu input ad yang tidak terisi dengan

Sesuai

20

benar

Input angka tidak bisa

dimasukan dengan

$\begin{array}{lll}\text { Sesuai } & 2 & 0\end{array}$

huruf

Halaman Cetak Laporan

Semua input sudah Sesuai terisi dengan benar

Salah datu input ada yang tidak terisi dengan

Sesuai

benar

Berdasarkan hasil rekapitulasi pengujian yang telah dilakukan didapatkan hasil jumlah jawaban dari responden yaitu mempunyai nilai $100 \%$ sesuai dengan pengujian fungsionalitas sistem menggunakan blackbox testing

Model ISO 25010 didefinisikan salah satu model pengujian dan evaluasi kualitas perangkat lunak dan merupakan bagian dari Software Product Quality Requirements and Evaluation (SQuaRE), teknik pengujian ini berkaitan dengan model kualitas perangkat lunak yang merupakan pengembangan dari model sebelumnya yaitu 9126. Berdasarkan tanggapan 6 responden dari CV Ra'Abas yang telah mengisi kuisioner dan diukur dengan rumus sebagai berikut :

Tabel 2. Hasil Pengujian Aspek Functional Suitability

\begin{tabular}{lcccccc}
\hline & \multicolumn{7}{c}{ Jawaban Responden } & \multirow{2}{*}{ Aspek } & SS & S & R & TS & ST & Tota \\
& & & & & S & l \\
\hline $\begin{array}{l}\text { Functional } \\
\text { Completeness }\end{array}$ & $\mathbf{2 2}$ & $\mathbf{1 8}$ & $\mathbf{8}$ & $\mathbf{0}$ & $\mathbf{0}$ & \\
$\begin{array}{l}\text { Functional } \\
\text { Correctness }\end{array}$ & $\mathbf{1 0}$ & $\mathbf{1 0}$ & $\mathbf{1 6}$ & $\mathbf{0}$ & $\mathbf{0}$ & \\
$\begin{array}{l}\text { Functional } \\
\text { Appropriatenes }\end{array}$ & $\mathbf{8}$ & $\mathbf{2 0}$ & $\mathbf{8}$ & $\mathbf{0}$ & $\mathbf{0}$ & \\
S & & & & & & \\
Skor Aktual & $\mathbf{2 0}$ & $\mathbf{1 9}$ & $\mathbf{9 6}$ & $\mathbf{0}$ & $\mathbf{0}$ & $\mathbf{4 8 8}$ \\
$\quad$ & $\mathbf{0}$ & $\mathbf{2}$ & & & & \\
$\quad$ Skor Ideal & $\mathbf{1 2}$ & $\mathbf{1 2}$ & $\mathbf{1 2}$ & $\mathbf{1 2}$ & $\mathbf{1 2 0}$ & $\mathbf{6 0 0}$ \\
& $\mathbf{0}$ & $\mathbf{0}$ & $\mathbf{0}$ & $\mathbf{0}$ & & \\
\hline
\end{tabular}

$$
\begin{aligned}
& \% \text { SkorTotal }=\frac{\text { skorAktual }}{\text { skorIdeal }} \times 100 \% \\
& =(488 / 600) * 100 \% \\
& =\mathbf{8 1 , 3 3 \%}
\end{aligned}
$$

Dari hasil pengolahan data tanggapan responden Aspek Functional Suitability maka didapatkan skor total yaitu 81,33\%. Berdasarkan hal tersebut maka Aspek Functional Suitability memiliki kriteria Baik untuk aplikasi pengadaan dan pendistribusian barang.

Tabel 3. Hasil Pengujian Aspek Usability

\begin{tabular}{lcccccc}
\hline \multirow{2}{*}{ Aspek } & \multicolumn{5}{c}{ Jawaban Responden } & \multirow{2}{*}{ Total } \\
& SS & S & R & TS & STS & \\
\hline Appropriateness & $\mathbf{1 0}$ & $\mathbf{1 1}$ & $\mathbf{1 5}$ & $\mathbf{0}$ & $\mathbf{0}$ & \\
Recognizability & & & & & & \\
Learnability & $\mathbf{8}$ & $\mathbf{9}$ & 7 & $\mathbf{0}$ & $\mathbf{0}$ & \\
Skor Aktual & $\mathbf{9 0}$ & $\mathbf{8 0}$ & $\mathbf{6 6}$ & $\mathbf{0}$ & $\mathbf{0}$ & $\mathbf{2 3 6}$ \\
$\quad$ Skor Ideal & $\mathbf{6 0}$ & $\mathbf{6 0}$ & $\mathbf{6 0}$ & $\mathbf{6 0}$ & $\mathbf{6 0}$ & $\mathbf{3 0 0}$ \\
\hline
\end{tabular}

$$
\begin{aligned}
& \% \text { SkorTotal }=\frac{\text { skorAktual }}{\text { skorIdeal }} \times 100 \% \\
& =(236 / 300) * 100 \% \\
& =\mathbf{7 8 , 6 6 \%}
\end{aligned}
$$

Dari hasil pengolahan data tanggapan responden Aspek Usability maka didapatkan skor total yaitu 78,66\%. Berdasarkan hal tersebut maka Aspek Usability memiliki kriteria Baik untuk aplikasi pengadaan dan pendistribusian barang.

Hasil pengolahan data rekapitulasi pengujian ISO 25010 berdasarkan 2 kriteria yang digunakan dari aplikasi yang telah dibuat adalah

Tabel 4. Hasil Pengujian ISO 25010

\begin{tabular}{cccccc}
\hline $\begin{array}{c}\text { N } \\
\text { o }\end{array}$ & $\begin{array}{l}\text { Aspek / } \\
\text { Kriteria }\end{array}$ & $\begin{array}{c}\text { Skor } \\
\text { Aktual }\end{array}$ & $\begin{array}{c}\text { Skor } \\
\text { Ideal }\end{array}$ & $\begin{array}{c}\text { \% } \\
\text { Skor } \\
\text { Total }\end{array}$ & $\begin{array}{c}\text { Krite } \\
\text { ria }\end{array}$ \\
\hline 1 & $\begin{array}{l}\text { Functional } \\
\text { Suitability }\end{array}$ & 488 & 600 & 81,33 & Baik \\
2 & $\begin{array}{l}\text { Usability } \\
2\end{array}$ & 236 & 300 & 78,66 & Baik
\end{tabular}


Total

724

900

Dari keseluruhan pengujian ISO 25010 untuk sistem pengadaan dan pendistribusian barang pada $\mathrm{CV}$ Ra'Abas Bandar Lampung mendapatkan hasil Baik sebesar $80,44 \%$.

\section{Simpulan}

Berdasarkan hasil uraian yang telah dipaparkan pada babbab sebelumnya makan dapat diambil simpulan yaitu Sistem pengadaan dan pendistribusian pada CV Ra'Abas ini dengan menggunakan metode Desain Sprint yaitu melakukan pemetaan, membuat sketsa dari aplikasi yang akan dibangun, mengambil keputusan dari hasil dari sketsa yang telah dibuat, membuat rancang bangun aplikasi pengadaan dan pendistribusian barang menggunakan bahasa pemrograman PHP dengan database MySql, dan melakukan pengujian dari aplikasi yang telah dibuat kepada pengguna. Hasil pengujian blackbox testing untuk sistem pengadaan dan pendistribusian barang pada CV Ra'Abas Bandar Lampung mendapatkan hasil Sangat Sesuai yaitu $100 \%$. Hasil pengujian ISO 25010 untuk sistem pengadaan dan pendistribusian barang pada $\mathrm{CV}$ Ra'Abas Bandar Lampung mendapatkan hasil Baik sebesar $80,44 \%$.

\section{Daftar Pustaka}

[1] Y. Febriani, "REKAYASA KEBUTUHAN APLIKASI MONITORING KINERJA TENAGA PENJUAL PRODUK KREDIT BANK XYZ MENGGUNAKAN MODEL SYSTEM ENGINEERING LIFE CYCLE," Sitech, vol. Vol 1, No, pp. 1-6, 2018.

[2] B. J. Kaleb, "Penerapan Sistem Informasi Manajemen Dan Pengawasannya Di Kantor Pelayanan Pajak Pratama Manado," J. EMBA J. Ris. Ekon. Manajemen, Bisnis dan Akunt., vol. 7, no. 1, pp. 781-790, 2019, doi: 10.35794/emba.v7i1.22555.

[3] T. Arnova and I. Ahmad, "Sistem Informasi EDocument Korespodensi Pada Korem 043/Gatam," J. Ilm. Rekayasa dan Manaj. Sist. Inf., vol. 1, no. 2, pp. 15-18, 2015.

[4] M. Taufiq, A. H. Sumitro, P. Studi, and M.
Informatika, "Implementasi desain sprint dalam pembuatan sistem informasi prakerin untuk smk dan cv," pp. 643-657, 2019.

[5] A. Prasetyo, H. M. Az-zahra, and A. H. Brata, "Perancangan Aplikasi Bimbingan Skripsi Berbasis Mobile dengan menggunakan Pendekatan Design Sprint ( Studi Kasus Bimbingan Skripsi Fakultas Ilmu Komputer Universitas Brawijaya )," J. Pengemb. Teknol. Inf. dan Ilmu Komput., vol. 3, no. 6, pp. 5808-5816, 2019, [Online]. Available: http://jptiik.ub.ac.id/index.php/j-

ptiik/article/download/5581/2633/.

[6] S. Ahdan and S. Setiawansyah, "Android-Based Geolocation Technology on a Blood Donation System (BDS) Using the Dijkstra Algorithm," IJAIT (International J. Appl. Inf. Technol., pp. 115, 2021.

[7] H. Sulistiani, A. Yuliani, and F. Hamidy, "Perancangan Sistem Informasi Akuntansi Upah Lembur Karyawan Menggunakan Extreme Programming," Technomedia J., vol. 6, no. 01 Agustus, 2021.

[8] D. A. Megawaty, D. Alita, and P. S. Dewi, "PENERAPAN DIGITAL LIBRARY UNTUK OTOMATISASI ADMINISTRASI PERPUSTAKAAN," J. Soc. Sci. Technol. Community Serv., vol. 2, no. 2, pp. 121-127, 2021.

[9] Y. Rahmanto and R. Y. Utama, "Penerapan Teknologi Web3D Berbasis Android Sebagai Media Pembelajaran Gerakan Dasar Silat," $J$. TAM (Technology Accept. Model., vol. 9, no. 1, pp. 7-14, 2018, [Online]. Available: http://ojs.stmikpringsewu.ac.id/index.php/Jurnal Tam/article/view/593.

[10] A. F. Ramadhan, A. D. Putra, and A. Surahman, "APLIKASI PENGENALAN PERANGKAT KERAS KOMPUTER BERBASIS ANDROID MENGGUNAKAN AUGMENTED REALITY (AR)," J. Teknol. dan Sist. Inf., vol. 2, no. 2, pp. 24-31, 2021.

[11] M. Audrilia and A. Budiman, "Perancangan Sistem Informasi Manajemen Bengkel Berbasis Web (Studi Kasus: Bengkel Anugrah)," J. Madani Ilmu Pengetahuan, Teknol. dan Hum., vol. 3, no. 1, pp. 1-12, 2020. 